Pomáhajúce profesie, roč. 3, č. 1, 2020, 41-50

\title{
SEBASÚCIT VO VZŤAHU K OPTIMÁLNEMU PROSPEROVANIU U ŠTUDENTOV PSYCHOLÓGIE
}

\author{
Šeboková, Gabriela, Filipčíková, Laura \\ Katedra psychologických vied FSVaZ UKF v Nitre \\ gabriela.sebokova@gmail.com
}

\begin{abstract}
Abstrakt: Ciel'om výskumu bolo analyzovat' vzt'ah medzi sebasúcitom a optimálnym prosperovaním (5 indikátorov: zaujatie činnost'ou, vytrvalost', optimizmus, zapojenie do sociálnych vzt'ahov a št'astie) u študentov psychológie. Sebasúcit bol skúmaný prostredníctvom dimenzií indikujúcimi prítomnost' súcitu so sebou a indikujúcimi neprítomnost' súcitu so sebou. Výskumnú vzorku tvorilo 90 študentov psychológie z rôznych slovenských univerzít, vo veku od 18 do $24 \operatorname{rokov}(M=21,42, S D=1,19)$. Použité boli sebavýpoved'ové dotazníky Self-Compasion Scale (Neff, 2003) a The EPOCH Measure of Adolescent Well-being, (Kern, 2016). Výsledky poukázali na významný pozitívny vzt'ah medzi prítomnost'ou sebasúcitu k trom faktorom prosperovania - koptimizmu, zapojeniu do sociálnych vzt’ahov a ku št’astiu. Významný negatívny vzt’ah sa preukázal medzi neprítomnost'ou sebaúcitu a optimizmom, zapojením do sociálnych vzt'ahov a št'astím. Zistenia naznačili, že sebasúcit môže byt' významným zdrojom duševného zdravia budúcich psychológov. Kl'účové slová: sebasúcit, optimálne prosperovanie, študenti psychológie
\end{abstract}

\section{ÚVOD}

Problematika duševného zdravia, ktorého významnou súčast’ou je duševná pohoda (well-being), je v súčasnosti kl'účovou témou v slovenskom, európskom aj medzinárodnom kontexte. Svetová zdravotnícka organizácia aj Európska komisia kladú za prioritu podporu a posilňovanie wellbeingu a optimálneho fungovania u adolescentov, ktoré bolo doteraz dlhodobo zanedbávané. Viaceré výskumy potvrdzujú nižšiu životnú angažovanost', rezignáciu, demotiváciu a chýbanie sociálnych a emocionálnych kompetencií slovenských žiakov a študentov (Čerešník, 2016; Gajdošová a kolektív, 2018). Z nášho pohl'adu je preto dôležité skúmat' faktory, ktoré well-being resp. optimálne prosperovanie u študentov môžu posilňovat'. Jedným z významných protektívnych faktorov optimálneho fungovania je sebasúcit, ktorý spočíva v hl'adaní významu života človeka namiesto toho, aby sa usiloval o potešenie a vyhýbal sa bolesti (Neff \& Knox, 2017). Angažovanost', schopnost' vytrvat' v náročných situáciách, práca s vlastnými emóciami, kvalitné vzt'ahy a prejavovat' súcit druhým a zároveň schopnost' prejavit' súcit aj sebe patria medzi klúčové kompetencie budúcich psychológov. Ciel'om predkladanej štúdie je preto preskúmat' súvislosti medzi sebasúcitom a optimálnym prosperovaním u budúcich pomáhajúcich profesionálov, študentov psychológie.

\subsection{Sebasúcit}

Pre pochopenie sebasúcitu je dôležité v prvom rade definovat’ súcit. Súcit znamená, že jednotlivca sa dotýkajú utrpenia druhých, je otvorený voči bolestiam druhých, pričom sa im nevyhýba ani ich neignoruje, ale naopak, prejavuje voči nim láskavost' a túžbu zmiernit' ich utrpenie (Wispé, 1991). Súcit sa môže rozšírit' smerom k sebe samému, ked' utrpenie nastane bez vlastného zavinenia alebo ked' utrpenie pramení z jednotlivcových chýb, zlyhaní alebo osobných nedostatkov (Neff, 2011). Podl'a Neffovej (2003 a, b) predstavuje sebasúcit zdravú formu sebaprijatia, ide o láskavý a 
prijatel'ný postoj voči sebe samému vo chvíl'ach neúspechu a individuálnych nedostatkov. Koncept vychádza z budhistickej teórie, ktorá predpokladá rovnakú dôležitost' cítit' súcit so sebou ako aj s inými (Neff, 2003a).

Súcit so sebou obsahuje tri hlavné zložky, ktoré sa prekrývajú a vzájomne sa ovplyvňujú: 1. sebaláskavost' (self-kindness) vs. sebaposúdenie (self-judgment), 2. všeobecná l'udskost' (common humanity) vs. izolácia (isolation), 3. všímavost' (mindfulness) vs. prílišná identifikácia (overidentification) (Neff, 2003b).

Sebaláskavost' súvisí s toleranciou a porozumením pre naše chyby a nedostatky, pričom si uvedomujeme, že dokonalost' je nedosiahnutel'ná. Sebaposúdenie naopak predstavuje neustále kritizovanie samého seba za svoju nedokonalost' (Neff\& Germer, 2017).

Druhý faktor všeobecná l'udskost' spočíva v uznaní toho, že všetci l'udia zlyhávajú, robia chyby a nejakým spôsobom sa cítia nedokonalo (Neff, 2011). Súcit so sebou vidí nedokonalost' ako súčast' každého človeka, takže slabosti človeka sú vnímané zo širokej perspektívy. Podobne aj t'ažké životné okolnosti sú chápané vo svetle všeobecnej l'udskosti, takže človek má pocit, že je skôr prepojený s inými, ked' prežíva utrpenie. Na druhej strane izolácia predstavuje pocit človeka, že je izolovaný od ostatných, ked' zvažuje svoje osobné chyby alebo zažíva t’ažké časy. Jednotlivci sa domnievajú, že je nezvyčajné zlyhat', mat' slabiny alebo trpiet' t'ažkost'ami. Tento iracionálny proces myslenia spôsobuje silné pocity izolácie (Neff, 2011).

Všímavost', tretia zložka súcitu so sebou, spočíva v tom, aby bol jednotlivec jasne a vyvážene oboznámený so súčasnými momentálnymi skúsenost'ami tak, aby ani neignoroval ani neruminoval nad negatívnymi aspektmi seba alebo svojho života (Brown \& Ryan, 2003). Všímavost' tiež zabraňuje tomu, aby človek situáciu preháňal a bol pohrúžený do vlastnej bolesti - to je proces, ktorý Neffová (2003b) označila za "prílišnú identifikáciu". Prílišná identifikácia znamená, že l'udia majú tendenciu preháňat' a obsedantne v sebe upevňovat' negatívne myšlienky a emócie, čo znamená, že nemôžu jasne vidiet' seba alebo ich t’ažkosti (Neff, 2011).

\subsection{Optimálne prosperovanie}

Well-being predstavuje v psychológii intenzívne skúmaný, no stále nie jednoznačne definovaný konštrukt. Svetová zdravotnícka organizácia ho charakterizuje ako dôležitú súčast’ zdravia, „stav úplnej telesnej, duševnej a spoločenskej pohody“ (Kebza \& Šolcová, 2003). Odborníci na well-being nahliadajú z viacerých perspektív, medzi najvýznamnejšie patria subjektívny well-being (tzv. hedonistická perspektíva), psychologických well-being (tzv. edaimonický prístup) a optimálne prosperovanie (flourishing). V predkladanej štúdii sme vychádzali z konceptu optimálneho prosperovania, ktorý na well-being nenahliada len ako na prítomnost' štastia alebo iných pozitívnych emócií, ale skôr ako na prosperovanie vo viacerých oblastiach života (Adler \& Seligman, 2016). Konštrukt duševnej pohody je operacionalizovaný prostredníctvom viacerých prvkov resp. indikátorov, ktoré $\mathrm{k}$ duševnej pohode prispievajú ale nedefinujú ju. Ide o multidimenzionálny prístup, ktorý sa snaží definovat’ najvýznamnejšie pozitívne faktory, ktoré prispievajú k optimálnemu fungovaniu jednotlivcov. Modelov optimálneho fungovania dospelých jednotlivcov aj adolescentov bolo vytvorených viacero. V predkladanej štúdii vychádzame z teoretického modelu optimálneho prosperovania (tzv. flourishingu) Seligmana, ktorý ho označil akronymom PERMA. Ide o pät' kl'účových prvkov: pozitívne emócie (positive emotion), zaujatie činnost’ou (engagement), pozitívne emócie (positive relations), zmysluplnost' (meaning) a úspešný výkon (accomplishment).

Model PERMA však bol Seligmanom vytvorený primárne na dospelú populáciu. Na populáciu adolescentov model optimálneho prosperovania rozšírila a aplikovala Kernová et al. (2016). Autorka vytvorila teoretický model, ktorý popisuje pät' pozitívnych charakteristík, postojov a prejavov správania, ktoré podl'a teoretických predpokladov podporujú prosperovanie v dospelosti 
v zmysle koncepcie PERMA. Optimálne prosperovanie autorka nedefinuje ako len neprítomnost' psychologických a behaviorálnych problémov, ale aj ako prítomnost' silných stránok a „dobrého života“. Model EPOCH (akronym podl'a začiatočných písmen anglického názvu) tvorí pät' faktorov: zaujatie činnost'ou (engagement) - kapacita dospievajúceho byt' pohltený určitou činnost'ou, angažovanost' a záujem o úlohy a aktivity v živote; vytrvalost' (perseverance) - schopnost' nasledovat' a napíňat' ciele aj v prípade prekážok; optimizmus (optimism)- nádej a dôvera v pozitívnu budúcnost', tendencia pozerat' sa na život z lepšej stránky a atribuovat' udalosti ako dočasné, externé a špecifické; zapojenie do vzt’ahov (connectedness) - predstava adolescentov, že sú milovaní, podporovaní a oceňovaní a poskytovanie podpory a priatel'stva druhým; št’astie (happiness) - stabilnejšia pozitívna nálada a emócie prežívané v súvislosti s vlastným životom adolescenta (Kern et al., 2016).

\subsection{Vzt’ah sebasúcitu a optimálneho prosperovania}

Na optimálnom prosperovaní jednotlivca sa podiel'a viacero rozdielnych zdrojov, tak osobnostných, kognitívnych ako aj sociálnych (Blatný \& Šolcová, 2016; Lippman et al., 2014; Rodriguez-Fernandez et al., 2016). Jedným z klúčových osobnostných zdrojov prosperovania je sebapercepcia. Mnohé štúdie poukazujú na to, že pozitívne vnímanie seba samého prináša očakávané výsledky (Reeve \& Jang, 2006) a spája sa s well-beingom, spokojnost'ou, št'astím a úspechom (Baby, 2012). Z uvedeného vyplýva, že sebasúcit, ktorý je definovaný ako zdravá forma sebaprijatia (Neff, 2003), môže predstavovat' dôležitý protektívny faktor optimálneho fungovania $\mathrm{u}$ adolescentov.

Aj výskumy potvrdzujú, že súcit so sebou je silným prediktorom psychického zdravia (Neff, Kirkpatrick, \& Rude, 2007a). Vyššie úrovne súcitu so sebou sa spájajú s nižšou úrovňou depresie, úzkost'ou, maladaptívnym perfekcionizmom, potláčaním myslenia, strachom $\mathrm{z}$ neúspechu a egocentrizmom (MacBeth\& Gumley, 2012; Neff, 2003a; Neff, Hseih, \& Dejitthirat, 2005; Neff, Kirkpatrick, \& Rude, 2007b; Neff \& McGehee, 2010). Sebasúcit tiež koreluje s pozitívnymi indikátormi well-beingu. Autori zistili pozitívne korelácie sebasúcitu so št'astím, optimizmom, pozitívnym vplyvom, múdrost'ou, osobnou iniciatívou a zvedavost'ou (Neff, Kirkpatrick, \& Rude, 2007a; Hollis-Walker \& Colosimo, 2011), s vnútorným záujmom o učenie a so zdravšími stratégiami zvládania stresu po neúspešných skúškach (Hseih \& Dejitthirat, 2005) a kvalitnejšími interpersonálnymi vzt’ahmi (Neff \& Pommier, 2013; Yarnell \& Neff, 2013).

Pozitívny vplyv sebasúcitu na duševné zdravie bol potvrdený aj v experimentálnych štúdiách. Leary, Tate, Adams, Allen a Hancock (2007) zistili, že súcit so sebou vedie l’udí k uznaniu ich úlohy v negatívnych udalostiach bez toho, aby sa cítili zahltení negatívnymi emóciami.

V posledných rokoch sa súcit so sebou začal skúmat' aj v kontexte jeho prítomnosti/neprítomnosti a to vo vzt’ahu k well-beingu aj k psychopatologickým symptómom. Výsledky výskumov ukázali výrazne silnejšie asociácie negatívnych dimenzií súcitu so sebou (sebaposúdenie, izolácia a prílišná identifikácia)so psychopatológiou, ako pozitívne dimenzie súcitu so sebou (sebaláskavost', všeobecná l'udskost' a všímavost') (Muris \& Petrocchi, 2016; Neff et al., 2018). Podobné zistenia autori reflektovali aj v súvislosti s well-beingom - konkrétne s dimenziami nádej, optimizmus, št'astie, životná spokojnost', vd'ačnost', vychutnávanie a pozitívny vplyv. Neffová (2018) zistila, že pre približne polovicu skúmaných výsledkov (24 z 50) boli negatívne dimenzie súcitu so sebou silnejšie asociované s well-beingom ako pozitívne dimenzie súcitu so sebou, hoci pozitívne dimenzie boli stále významným prediktorom jednotlivých indikátorov well-beingu. Podl'a autorky tieto výsledky podporujú predstavu, že zložky súcitu so sebou vzájomne pôsobia ako systém. 


\subsection{Predkladaná štúdia}

Viaceré výskumy a metaanalýzy konzistentne potvrdzujú, že schopnost' byt' láskavý k sebe vo chvíl'ach, ked' stojí tvárou v tvár neúspechom a individuálnym nedostatkom, je významným prediktorom optimálneho prosperovania u dospelých jednotlivcov aj dospievajúcich (Neff, 2011; Zessin et al., 2015). Podl'a Neffovej (2011)môže sebasúcit ponúknut' zdravší a trvalejší spôsob, ako sa cítit' dobre. Práve psychológia je odbor štúdia a neskôr profesie, v rámci ktorej by mali byt' jednotlivci pripravení poskytovat’ súcit nielen druhým ale aj voči sebe samým. Zaujímalo nás preto, aká je úroveň sebasúcitu u študentov psychológie na Slovensku a či úroveň sebasúcitu predikuje jednotlivé oblasti optimálneho prosperovania. Predpokladali sme pritom, že prítomnost’ súcitu so sebou (a jeho dimenzie) budú v pozitívnom vzt’ahu kjednotlivým indikátorom optimálneho prosperovania, zatial' čo neprítomnost' súcitu so sebou (a jeho dimenziách) bude v negatívnom vzt’ahu s indikátormi prosperovania.

\section{METÓDY}

\subsection{Výskumná vzorka}

Výskumu sa celkovo zúčastnilo 90 študentov psychológie vo veku od 18 do 24 rokov $(\mathrm{M}=21,42$; $\mathrm{SD}=1,19)$. Vzhl'adom na špecifické demografické zloženie študentov psychológie vzorku tvorilo 78 žien a 12 mužov. Na výber respondentov bola zvolená metóda snehovej gule. Zber dát prebiehal kombináciou osobného a online zberu. Online dotazník vyplnilo 51 študentov psychológie z rôznych slovenských univerzít - konkrétne 6 študentov $(6,7 \%)$ z Trnavskej univerzity v Trnave, 12 študentov (13,3\%) z Katolíckej univerzity v Ružomberku a 23 študentov (25,6\%) z Univerzity Komenského v Bratislave. Zvyšných 49 študentov psychológie (54,4\%) z Univerzity Konštantína Filozofa vypíňalo dotazník osobne. Od respondentov bol získaný informovaný súhlas.

\subsection{Metodiky}

Škála sebasúcitu (Self-Compassion Scale (SCS)- K. D. Neff, 2003, slovenský preklad Halamová, Kanovský, \& Pacúchová, 2017).SCS meria súcit so sebou prostredníctvom šiestich subškál, pričom tri z nich - sebaláskavost', všeobecná l'udskost' a všímavost' - merajú prítomnost' súcitu so sebou (pozitívne dimenzie), a d’alšie tri - sebaposúdenie, izolácia a prílišná identifikácia - merajú neprítomnost' súcitu so sebou (negatívne dimenzie). SCS obsahuje 26 položiek, na ktoré respondenti odpovedajú na 5 bodovej likertovej škále (1 - takmer nikdy, 2 - niekedy, 3 - často, 4 vel'mi často, 5 - takmer vždy). Autori deklarovali dobré psychometrické vlastnosti slovenskej verzie dotazníka (Halamová, Kanovský, \& Pacúchová, 2017). V predkladanej štúdii dosiahol koeficient Cronbachovej alfy nasledujúce hodnoty alfa: sebaláskavost' $\alpha=, 79$; sebaposúdenie $\alpha=$ ,75; všeobecná l'udskost' $\alpha=, 67$; izolácia $\alpha=, 79$; všímavost' $\alpha=, 75$; prílišná identifikácia $\alpha=, 78$.

The EPOCH Measure of Adolescent Well-being - M. L. Kern et al.2016, slovenský preklad Šeboková, Uhláriková, Halamová, 2019). Dotazník je tvorený 20 položkami, 4 pre každý faktor, na ktoré respondenti odpovedajú na 5 bodovej škále (1 - takmer nikdy / vôbec nie ako ja, 2 - niekedy / trochu ako ja, 3 - často / viac-menej ako ja, 4 - vel'mi často / zväčša ako ja, 5 - takmer vždy / úplne ako ja). Položky v dotazníku sú rozdelené do piatich faktorov podl'a teórie EPOCH: zaujatie činnost'ou, vytrvalost', optimizmus, zapojenie do sociálnych vzt'ahov a št'astie. Slovenská verzia dotazníka vykazuje uspokojivé psychometrické vlastnosti (Šeboková, UHláriková, \& Halamová, 2019). V predkladanej štúdii dosiahol koeficient Cronbachovej alfy nasledujúce hodnoty alfa: $\mathrm{E} \alpha=$ ,84; P $\alpha=, 84 ; \mathrm{O} \alpha=, 81 ; \mathrm{C} \alpha=, 84 ; \mathrm{H} \alpha=, 86$.

Pri vypĺňaní oboch dotazníkov respondenti uvádzali aj základné demografické údaje - pohlavie, vek, vysoká škola a pre potvrdenie aj odbor, ktorý študujú. 


\section{3 Štatistická analýza}

Získané dáta sme spracovávali pomocou štatistického programu SPSS 21.0. V prvom kroku sme sa zamerali na zist'ovanie normality rozloženia dát, na jej základe sme neskôr použili parametrický test - Pearsonovu korelačnú analýzu, a neparametrický test - Spearmanovu korelačnú analýzu.

\section{VÝSLEDKY}

Deskriptívne charakteristiky skúmaných premenných uvádzame vtabul'ke č.1. Pohl'ad na priemerné hodnoty škál sebasúcitu ukazuje, že dimenzie indikujúce neprítomnost’ sebasúcitu sa pohybujú okolo stredových hodnôt o niečo vyššie hodnoty ako stredové dosiahli študenti psychológie v dimenziách indikujúcich prítomnost' sebasúcitu (najmä v dimenzii všímavost'). V negatívnych dimenziách dosiahli študenti najvyššiu variabilitu hodnôt, čo poukazuje na väčšiu diferencovanost'.

Priemerné skóre škál EPOCH sa pohybujú v horných častiach pásma hodnôt, najvyššie hodnoty dosiahli študenti psychológie v škále zapojenie do sociálnych vzt’ahov, kde dosahovali aj najnižšiu variabilitu odpovedí.

Tabul'ka č.1 Deskriptívna analýza sebasúcitu a faktorov optimálneho prosperovania EPOCH

\begin{tabular}{lllllll}
\hline & $\mathrm{n}$ & $\mathrm{M}$ & $\mathrm{Mdn}$ & $\mathrm{SD}$ & Skew & Kurt \\
\hline Pozitívne dimenzie SC & 90 & 41,06 & 41,00 & 8,19 &,- 309 &,- 209 \\
Negatívne dimenzie SC & 90 & 39,84 & 39,00 & 10,54 &, 092 &,- 897 \\
Sebaláskavost' & 90 & 14,80 & 15,00 & 3,89 &,- 182 &,- 199 \\
Sebaposúdenie & 90 & 14,77 & 14,00 & 2,24 &,- 003 &,- 725 \\
Všeobecná l'udskost' & 90 & 12,46 & 13,00 & 3,20 &,- 172 &,- 586 \\
Izolácia & 90 & 11,91 & 12,00 & 3,77 &, 213 &,- 794 \\
Prílišná identifikácia & 90 & 13,15 & 13,00 & 3,63 &,- 208 &,- 863 \\
Všímavost' & 90 & 13,80 & 14,00 & 3,01 &,- 128 &,- 383 \\
Optimálne prosperovanie & 90 & 75,73 & 76,00 & 10,90 &,- 261 &,- 005 \\
Zaujatie činnost'ou & 90 & 13,77 & 14,00 & 3,15 &,- 267 &,- 004 \\
Vytrvalost' & 90 & 14,52 & 15,00 & 3,52 &,- 175 &,- 834 \\
Optimizmus & 90 & 14,13 & 14,00 & 3,17 &,- 030 &,- 377 \\
Zapojenie do sociálnych vzt'ahov & 90 & 18,10 & 19,00 & 2,51 & $-1,567$ & 2,428 \\
Št’astie & 90 & 15,20 & 16,00 & 3,34 &,- 706 &, 064 \\
\hline
\end{tabular}


Pomáhajúce profesie, roč. 3, č. 1, 2020, 41-50

Tabul'ka č.2 Korelačná analýza sebasúcitu a optimálneho prosperovania EPOCH

\begin{tabular}{lccccc}
\hline & $\mathrm{E}$ & $\mathrm{P}$ & $\mathrm{O}$ & $\mathrm{C}$ & $\mathrm{H}$ \\
\hline Prítomnost' SC &, 13 &,- 05 &, $48^{* * *}$ &, $34^{* *}$ &, $40^{* * *}$ \\
Sebaláskavost' &, 11 &,- 14 &, $47^{* * *}$ &, $26^{*}$ &, $39^{* * *}$ \\
Všeobecná l'udskost' &, 01 &,- 02 &, 19 &, $30^{* *}$ &, 17 \\
Všímavost' &, 20 &, 08 &, $48^{* * *}$ &, $39^{* * *}$ &, $39^{* * *}$ \\
Neprítomnost' SC &,- 15 &,- 07 &,$- 50^{* * *}$ &,$- 30^{* *}$ &,$- 48^{* * *}$ \\
Sebaposúdenie &,- 13 &,- 04 &,$- 46^{* * *}$ &,$- 30^{* *}$ &,$- 43^{* * *}$ \\
Izolácia &,- 18 &,- 10 &,$- 45^{* * *}$ &,$- 33^{* *}$ &,$- 46^{* * *}$ \\
Prílišná identifikácia &,- 10 &,- 04 &,$- 39^{* * *}$ &,- 19 &,$- 41^{* * *}$ \\
\hline
\end{tabular}

Vysvetlivky: E - zaujatie, P - vytrvalost', $\mathrm{O}$ - optimizmus, C - zapojenie do sociálnych vzt'ahov, $\mathrm{H}$ št'astie

${ }^{*} \mathrm{p}<, 05,{ }^{* *} \mathrm{p}<, 01,{ }^{* * *} \mathrm{p}<, 001$

Výsledky korelačnej analýzy (tabul'ka č. 2) nepreukázali štatisticky významné vzt’ahy medzi prítomnost'ou súcitu (a jeho dimenziami), neprítomnost'ou súcitu (a jeho dimenziami) s dvoma indikátormi prosperovania zaujatost' činnost'ou a vytrvalost'. Štatisticky významné, stredne silné vzt’ahy sa ukázali medzi dimenziami prítomnosti a neprítomnosti sebasúcitu (okrem všeobecnej l'udskosti) $\mathrm{s}$ indikátormi prosperovania optimizmus $(\mathrm{r}=, 39-\mathrm{r}=, 50, \mathrm{p}<, 001)$ a št'astie $(\mathrm{r}=, 39-\mathrm{r}$ $=, 48, \mathrm{p}<, 001)$. Zapojenie do sociálnych vzt’ahov korelovalo s dimenziami prítomnosti a neprítomnosti sebasúcitu štatisticky významne, sila vzt’ahov bola slabá až stredne silná $(\mathrm{r}=, 26-$ $\mathrm{r}=, 39, \mathrm{p}<, 001$ ). Dimenzie prítomnosti sebasúcitu pritom vykazovali pozitívne vzt'ahy, dimenzie neprítomnosti sebasúcitu negatívne vzt'ahy s faktormi EPOCH.

\section{DISKUSIA}

Ciel'om výskumu bolo analyzovat' súvislosti medzi sebasúcitom a optimálnym prosperovaním u študentov psychológie. Sebasúcit sme skúmali prostredníctvom jeho prítomnosti a neprítomnosti a ich dimenzií. Zaujímalo nás, či korelujú s piatimi indikátormi optimálneho prosperovania: zaujatie činnost'ou, vytrvalost', optimizmus, zapojenie do sociálnych vzt'ahov a št’astie.

V prvom kroku sme sa zamerali na zmapovanie úrovne sebasúcitu u študentov psychológie v našej vzorke. Zistenia poukázali na mierne vyššiu úroveň sebasúcitu u budúcich psychológov, čo potvrdilo aj porovnanie s priemerným skóre bežnej populácie vo výskume Halamovej, Kanovského a Pacúchovej (2017). Študenti psychológie dosahovali vo všetkých položkách vyšší priemer než bežná populácia. Výsledky naznačili, že budúci pomáhajúci profesionáli sa vyznačujú vyššou schopnost'ou prejavit' láskavý a prijatel'ný postoj voči sebe samému vo chvílach neúspechu a individuálnych nedostatkov. Budúci psychológovia dosahovali tiež vyššie hodnoty indikátorov optimálneho prosperovania, čo sa javí ako dôležitý predpoklad výkonu pomáhajúcej profesie.

Výsledky korelačnej analýzy ukázali, že prítomnost' sebasúcitu, ani jeho jednotlivé dimenzie sebaláskavost', všeobecná l'udskost' a všímavost', nie sú asociované s indikátorom optimálneho prosperovania zaujatie činnost'ou. Podobne chýbajúci sebasúcit a jeho dimenzie sebaposúdenie, izolácia a prílišná identifikácia, neboli vo významnom vzt’ahu so zaujatím. Rovnaké výsledky sme zaznamenali pri faktore vytrvalost', ktorá nebola významne asociovaná so žiadnou z dimenzií prítomnosti ani neprítomnosti sebasúcitu.

Výsledky naznačili, že schopnost' zahíbit’ sa do činnosti, byt' angažovaný a vytrvalý v aktivitách a úlohách u študentov psychológie nezávisí od ich schopnosti byt’ k sebe láskavý a zhovievavý. Naše zistenia nie sú v úplnej zhode s predchádzajúcimi výskumami, ktoré ukázali, že vyššia miera 
sebasúcitu podporuje vnútornú motiváciu a vnímané kompetencie (Neff, Hsieh, \& Dejitterat, 2005), teda adaptívne prejavy akademickej motivácie, s ktorými sú zaujatie činnost'ou a vytrvalost' úzko spojené (Šeboková, Uhláriková, \& Halamová, 2019; Babenko, et al., 2018). Vysvetlenie možno nájst' vo vzt'ahu sebasúcitu a motivácie k výkonu. Podl'a Neffovej et al. (2005) sebasúcit nesúvisí so štandardami výkonu, ktoré si pre seba stanovujeme. Človek, ktorý vie byt' k svojim nedostatkom zhovievavý, je rovnako ctižiadostivý a na ciel' zameraný ako ostatní l’udia, no zároveň je schopný rozoznat' a prijat' fakt, že nie vždy je schopný stanovený ciel' dosiahnut'. V dôsledku toho zažíva menej úzkosti a využíva menej seba-hendikepujúcich stratégií ako napr. prokrastináciu. Naše výsledky tak naznačujú, že schopnost' prejavit' voči sebe pochopenie a prijatie nevedie k zníženiu našej životnej angažovanosti a vytrvalosti, no ani ju nezvyšuje.

Výsledky d’alej ukázali významné stredne silné vzt’ahy jednotlivých dimenzií sebasúcitu s optimizmom a št’astím u študentov psychológie. Ukázalo sa, že dospievajúci, ktorí dokážu byt’ k sebe láskaví, majú optimistickejší pohl'ad na život a zažívajú viac št’astia, ako l’udia, ktorí sú k sebe príliš kritickí a negativistickí. Zistenia sú v súlade s viacerými výskumami a metaanalýzami dokumentujúcimi pozitívny efekt (stredne vel'ký) sebasúcitu na pozitívne emócie a prežívanie (Zessin et al., 2005). Sebasúcit sa tak ukazuje ako dôležitý zdroj eudaimonického št’astia, zahŕňajúceho nájdený zmysel a význam, nielen snahu o získanie potešenia a vyhnutia sa bolesti (Neff \& Knox, 2017).

O niečo slabšie vzt'ahy sme zaznamenali medzi sebasúcitom a zapojením do sociálnych vzt’ahov. Výsledky naznačili, že schopnost' prejavit' láskavost' voči sebe neprináša benefity len jednotlivcovi ale aj jeho interpersonálnym vzt’ahom. Jednotlivci s vyššou mierou sebasúcitu sa cítia byt' viac milovaní a podporovaní blízkymi a zároveň poskytujú lásku podporu svojim blízkym. Výsledky podporujú predchádzajúce zistenia autorov, že vyššia miera sebasúcitu je spojená s lepšou psychologickou pohodou vo vzt'ahoch, s vyššou empatiou, schopnost'ou odpúšt'at' a zníženým distresom v reakcii na utrpenie druhých (Neff \& Pommier, 2013; Yarnell \& Neff, 2013). Tieto zistenia naznačujú dôležitú funkciu sebasúcitu u pomáhajúcich profesionálov (v našom prípade budúcich psychológov), nakol'ko sebasúcit dokáže udržiavat' a rozširovat' kapacitu jednotlivcov byt' tu a starat' sa o druhých, nakol'ko, zdá sa, poskytuje emočné zdroje potrebné pre starostlivost' o druhých. Avšak zistené slabé vzt’ahy korešpondujú s celkovo miernymi koreláciami medzi sebasúcitom a súcitom k druhým, nakol'ko l'udia väčšinou prejavujú viac súcitu k druhým ako k samým sebe.

Vo všeobecnosti výsledky poukázali na silnejšie asociácie medzi negatívnymi dimenziami sebasúcitu a indikátormi optimálneho prosperovania ako pozitívne dimenzie, čo podporuje predchádzajúce zistenia (Neff, 2018). Výsledky však ukazujú, že obe pozitívne aj negatívne dimenzie významne prispievajú k optimálnemu fungovaniu jednotlivcov.

\subsection{Limity výskumu}

Predkladaná štúdia má niekol'ko limitov. Prvým je kombinácia osobného aj online zberu dát. Zahrnutie aj online zberu nám však umožnilo zapojit' do výskumu študentov psychológie z viacerých slovenských univerzít a získat' tak variabilnejšiu vzorku. Druhým limitom výskumu je nižšie zastúpenie mužov vo vzorke, ktorí tvorili len necelých $11 \%$. Zloženie vzorky nám preto neumožnilo overovat' rodové rozdiely a výsledky nemožno rovnako zovšeobecnit' na mužov aj ženy. Faktom však ostáva, že zloženie vzorky vzhl'adom na pohlavie zodpovedá zastúpeniu mužov medzi študentmi psychológie v populácii. Limitom výskumu je tiež sebavýpoved'ový charakter použitých metodík, do budúcna by bolo vhodné overit' vplyv sebasúcitu aj v experimentálnej situácii. 


\section{ZÁVER}

Výsledky výskumu potvrdili významnú úlohu sebasúcitu v optimálnom fungovaní u študentov psychológie. Schopnost' byt' k sebe láskavý a prijat' svoje nedostatky bola asociovaná s optimistickejším pohl'adom na svet a budúcnost', prežívaným št'astím a kvalitnejšími vzt'ahmi. Zistenia naznačili, že sebasúcit môže byt' významným zdrojom duševného zdravia budúcich psychológov a ich schopnosti pomáhat' a starat' sa o druhých.

\section{LITERATÚRA}

Adler, A. \& Seligman, M. E. P. (2016). Using wellbeing for public policy: Theory, measurement, and recommendations. International Journal of Wellbeing, 6(1), 1-35. doi: 10.5502/ijw.v6i1.429

Baby, S. (2012). Development of Self-concept and Health. Social Science International, 28(2), 253263.

Blatný, M. \& Šolcová, I. (2016). Osobnostní předpoklady osobní pohody. Československá psychologie, 60(1), 2-12.

Brown, K. W. \& Ryan, R. M. (2003). The benefits of being present: Mindfulness and its role in psychological well-being. Journal of Personality and Social Psychology, 84(4), 822-848. doi: 10.1037/0022-3514.84.4.822

Čerešník, M. (2016). Duševná pohoda a prežívanie št'astia. Diagnostické skúsenosti v systéme vyššieho sekundárneho vzdelávania. In E. Gajdošová (Ed.) Škola v kontexte psychológie zdravia a pozitívnej psychológie, Praha, Wolters Kluwer, 260-266.

Gajdošová, E., Radnoti, E. \& Bisaki, V. (2018). Sociálno-emocionálne zdravie a prežívanie št’astia u študentov stredných škôl. Školský psychológ / Školní psycholog, 19(1), 101-111.

Halamová, J., Kanovský, M. \& Pacúchová, M.(2017). Self-Compassion Scale: IRT Psychometric Analysis Validation and Factor Structure - Slovak Translation. Psychologica Belgica, 57(4), 190209. doi: http://doi.org/10.5334/pb.398

Hollis-Walker, L. \& Colosimo, K. (2011). Mindfulness, self-compassion, and happiness in nonmeditators: A theoretical and empirical examination. Personality and Individual Differences, 50(2), 222-227.doi: 10.1016/j.paid.2010.09.033

Kebza, V. \& Šolcová, I. (2003). Well-being jako psychologický a zároveň mezioborově založený pojem. Československá psychologie, 18(4), 333-345.

Kern, M. L., Benson, L., Steinberg, E. A. \& Steinberg, L. (2016). The EPOCH Measure of Adolescent Well-Being. Psychological Assessment, 28(5), 586-597.doi: 10.1037/pas0000201

Leary, M. R., Tate, E. B., Adams, C. E., Allen, A. B. \& Hancock, J. (2007). Self-compassion and reactions to unpleasant self-relevant events: The implications of treating oneself kindly. Journal of Personality and Social Psychology, 92(5), 887-904.doi: 10.1037/0022-3514.92.5.887

Lippman, L. H., Ryberg, R., Terzian, M., Moore, K. A., Humble, J. \& McIntosh, H. (2014). Positive and protective factors in adolescent well-being. In A. Ben-Arieh, F. Casas, I. Frones \& J. E. Korbin (Eds.), Handbook of child well-being. New York: Springer.

Macbeth, A. \& Gumley, A. (2012). Exploring compassion: A meta-analysis of the association between self-compassion and psychopathology. Clinical Psychology Review, 32(6), 545-552. doi:10.1016/j.cpr.2012.06.003 


\section{Pomáhajúce profesie, roč. 3, č. 1, 2020, 41-50}

Muris, P., Otgar, H., Meesters C., Heutz, A. \& van den Hombergh (2018). Good and Bad Sides of SelfCompassion: A Face Validity Check of the Self-Compassion Scale and an Investigation of its Relations to Coping and Emotional Symptoms in Non-Clinical Adolescents. Journal of Child and Family Studies, 27(8), 2411-2421.doi: 10.1007/s10826-019-01353-4

Neff, K. D. (2003a). The development and validation of a scale to measure self-compassion. Self and Identity, 2(3) , 223-250. doi: 10.1080/15298860390209035

Neff, K. D. (2003b). Self-compassion: an alternative conceptualization of a healthy attitude toward oneself. Self and Identity, 2(2), 85-102. doi: 10.1080/15298860390129863

Neff, K. D., Hseih, Y. \& Dejitthirat, K. (2005). Self-compassion, achievement goals, and coping with academic failure. Self and Identity, 4(3), 263-287. doi: 10.1080/13576500444000317

Neff, K. D., Kirkpatrick, K. L. \& Rude, S. S. (2007a). An examination of self-compassion in relation to positive psychological functioning and personality traits. Journal of Research in Personality, 41(4), 908-916. doi:10.1016/j.jrp.2006.08.002

Neff, K. D., Kirkpatrick, K. L. \& Rude, S. S. (2007b). Self-compassion and adaptive psychological functioning. Journal of Research in Personality, 41(1), 139-154. doi:10.1016/j.jrp.2006.03.004

Neff, K. D. \& Vonk, R. (2009). Self-compassion versus global self-esteem: Two different ways of relating to oneself. Journal of Personality, 77(1), 23-50. doi: 10.1111/j.1467-6494.2008.00537.x

Neff, K. D. \& Mcgeehee, P. (2010). Self-compassion and psychological resilience among adolescents and young adults. Self and Identity, 9(3), 225-240. doi: 10.1080/15298860902979307

Neff, K. D. (2011). Self-compassion, self-esteem, and well-being. Social and Personality Psychology Compass, 5(1), 1-12. doi:10.1111/j.1751-9004.2010.00330.x

Neff, K. D. \& Pommier, E. (2013). The Relationship between Self-compassion and Other-focused Concernamong College Undergraduates, Community Adults, and Practicing Meditators. Self and Identity, 12(2), 1-17. doi:10.1080/15298868.2011.649546

Neff, K. D. (2016). The Self-Compassion Scale is a valid and theoretically coherent measure of selfcompassion. Mindfulness, 7(1), 264-274. doi: 10.1007/s12671-015-0479-3

Neff, K. D. \& Germer, C. (2017). Self-Compassion and Psychological Wellbeing. In : J. Doty (Ed.) Oxford Handbook of Compassion Science, Chap. 27. Oxford University Press.

Neff, K. D. \& Knox, M. C. (2017). Self-Compassion. In: V. Zeigler-Hill, T.K. Shackelford (eds.), Encyclopedia of Personality and Individual Differences. doi 10.1007/978-3-319-28099-8_1159-1

Neff, K. D. et al. (2018). The forest and the trees: Examining the association of self-compassion and its positive and negative components with psychological functioning. Self and identity, 17(6), 627645. https://doi.org/10.1080/15298868.2018.143658

Reeve, J. \& Jang, H. (2006). What teachers say and do to support students' autonomy during a learning activity. Journal of Educational Psychology, 98(1), 209-218. doi: 10.1037/00220663.98.1.209.

Rodríguez-Fernández, A., Ramos-Díaz, E., Fernández-Zabala, A., Goni, E., Esnaola, I. \& Goni, A. (2016). Contextual and Psychological Variables in a Descriptive Model of Subjective Well-Being and School Engagement. International Journal of Clinical and Health Psychology, 16(2), 166-174. https://doi.org/10.1016/j.ijchp.2016.01.003 
Šeboková, G., Uhláriková, J. \& Halamová, M. (2019). Faktorová štruktúra, reliabilita a validita dotazníka EPOCH na meranie well-beingu adolescentov. Československá psychológie, 63(3), 280 298.

Wispe, L. (1991). The psychology of sympathy. New York : Plenum

Yarnell, L. M. \& Neff, K. D. (2013). Self-compassion, interpersonal conflict resolutions, and wellbeing. Self and Identity, 12(2), 146-159. doi: 10.1080/15298868.2011.649545

Zessin, U., Dickhäuser, O. \& Garbade, S. (2015). The Relationship Between Self-Compassion and Well-Being: A Meta-Analysis. Applied psychology: health and well-being, 7(3), 340-364. doi:10.1111/aphw.12051

\title{
SELF-COMPASSION IN THE REALTION TO FLOURISHING IN PSYCHOLOGY STUDENTS
}

\begin{abstract}
The aim of the study was to analyse the relationship between selfcompassion and flourishing (its five indicators: engagement, perseverance, optimism, connectedness, happiness) in psychology students. Self-compassion was analysed through dimensions indicating presence of self-compassion and the absence of selfcompassion. The research sample consisted of 90 students of psychology attending several Slovak universities, aged $18-24$ years old $(M=21,42, S D=1,19)$. the selfreport measures Self-Compassion Scale (Neff, 2003) and The EPOCH Measure of Adolescent Well-being (Kern, 2016) were utilized. The results indicated significant positive relationship between presence of self-compassion and three indicators of flourishing - optimism, connectedness, and happiness. Significant negative relationship was found out between the absence of self-compassion and optimism, connectedness, and happiness. The findings suggested that self-compassion may be a significant contributor to the mental health of psychology students.
\end{abstract}

Klúčové slová: self-compassion, flourishing, psychology students 